\title{
PENGARUH PENDEKATAN CONTEXTUAL TEACHING AND LEARNING TERHADAP KEMAMPUAN BERPIKIR KREATIF MATEMATIS SISWA KELAS VIII SMP NEGERI 2 KONAWE SELATAN
}

\author{
Reski Agung Mantung ${ }^{1)}$, Hasnawati $^{2)}$, Lambertus ${ }^{3)}$ \\ ${ }^{1)}$ Alumni Jurusan Pendidikan Matematika, ${ }^{2,3)}$ Dosen Jurusan Pendidikan Matematika \\ FKIP Universitas Halu Oleo Email : ${ }^{1)}$ reskiam1997@gmail.com, hasnawati@gmail.com ${ }^{2)}$
}

\begin{abstract}
Abstrak
Penelitian ini dilatarbelakangi oleh hasil tes pendahuluan berpikir kreatif matematis bahwa siswa masih memiliki kemampuan berpikir kreatif matematis yang rendah. Jenis penelitian ini adalah eksperimen. Data yang digunakan dalam penelitian ini dikumpulkan dengan menggunakan lembar observasi aktivitas guru dan siswa serta tes kemampuan berpikir kreatif matematis berupa tes uraian sebanyak 4 butir soal dengan indikator berpikir lancar, berpikir luwes, berpikir merinci, dan berpikir asli. Berdasarkan hasil analisis data diperoleh kesimpulan bahwa nilai rata-rata hasil tes berpikir kreatif matematis siswa setelah diajar dengan pendekatan pembelajaran konvensional dan pendekatan Contextual Teaching and Learning berturut-turut untuk indikator berpikir lancar 79 dan 87, berpikir luwes 31 dan 60, berpikir merinci 18 dan 23, berpikir asli 30 dan 53. Ditinjau dari keaktifan siswa dalam pembelajaran, nilai rata-rata dari tes uraian, dan hasil uji statistik terdapat pengaruh pendekatan Contextual Teaching and Learning terhadap kemampuan berpikir kreatif matematis siswa kelas VIII SMP Negeri 2 Konawe Selatan.
\end{abstract}

Kata Kunci: contextual teaching and learning, kemampuan berpikir kreatif matematis

\section{AN ANALISIS OF MATHEMATICAL LITERACY ABILITY OF VIII 1 SMP NEGERI 9 KENDARI AND VIII ${ }_{7}$ SMP NEGERI 10 KENDARI}

\begin{abstract}
This research is based on the results of a preliminary creative mathematical test, it showed that students still have low mathematical creative thinking skills. The type of this research is experimental. The data of this research is collected using observation sheets of the techers and the students activities and the test of mathematical creative thinking skills in the form of description test in 4 items with the indicators of fluency, flexibility, elaboration originality. Based on the results of the data analysis, it can be concluded that the average value of students' mathematical creative thinking test results after being taught with conventional learning approaches and successive Contextual Teaching and Learning approaches for indicators fluency are 79 and 87, flexibility are 31 and 60, elaboration are 18 and 23, originality are 30 and 53. Judging from the activity of students in learning, the average value of the description test, and the results of statistical tests there is an influence of the Contextual Teaching and Learning approach to mathematical creative thinking skills of eighth grade students of Junior High School 2 South Konawe.
\end{abstract}

Keywords: Contextual Teaching and Learning, creative thinking skills 


\section{Pendahuluan}

Manusia tidak bisa lepas dari pendidikan. Pendidikan menurut Undang-Undang No. 20 tahun 2003 tentang Sisdiknas dalam pasal 1 merupakan usaha sadar dan terencana untuk mewujudkan suasana belajar dan proses pembelajaran agar peserta didik secara aktif mengembangkan potensi dirinya untuk memiliki kekuatan spiritual keagamaan, pengendalian diri, kepribadian, kecerdasan, akhlak mulia, serta keterampilan yang diperlukan dirinya, masyarakat, mengembangkan segala potensi yang dimiliki peserta didik melalui proses pembelajaran. Dengan demikian pendidikan tentu tidak terlepas dengan pembelajaran di sekolah yang menginginkan pembelajaran yang bisa menumbuhkan semangat siswa untuk belajar. Suatu pembelajaran tentunya juga mempunyai tujuan khusus yang hendak dicapai sesuai dengan target yang diinginkan. Dengan adanya tujuan ini akan menumbuhkan sikap yang akan menjadi pegangan guru dalam proses pembelajaran tersebut.

Matematika sebagai suatu ilmu pengetahuan mempunyai hubungan dan menjadi pendukung pendidikan berbagai bidang ilmu serta berbagai aspek kehidupan manusia. Matematika dalam aspek terapannya sangat dibutuhkan dalam perkembangan teknologi. Matematika pada hakikatnya (Noer, 2009: 523) mempunyai dua arah pengembangan yaitu untuk memenuhi kebutuhan masa kini dan kebutuhan masa yang akan datang. Kebutuhan masa kini yang dimaksud yaitu mengarahkan pembelajaran matematika untuk pemahaman konsep dan ide matematika yang kemudian diperlukan untuk menyelesaikan masalah matematika dan ilmu pengetahuan lainnya. Sedangkan yang dimaksud dengan kebutuhan masa yang akan datang adalah pembelajaran matematika memberikan kemampuan menalar yang logis, sistematik, kritis dan cermat, menumbuhkan rasa percaya diri, dan rasa keindahan terhadap keteraturan sifat matematika, serta mengembangkan sikap objektif dan terbuka yang sangat diperlukan dalam menghadapi masa depan yang senantiasa berubah. Karenanya, hakikat dan kegunaan matematika bukan hanya sebagai ilmu yang diajarkan di sekolah, bukan hanya sebatas memberikan kemampuan dalam perhitunganperhitungan kuantitatif saja, melainkan sebagai ilmu terapan yang dapat digunakan dalam kehidupan sehari-hari.

Kurikulum terbaru, yakni kurikulum 2013, dalam Permendikbud Nomor 81A Tahun 2013 menghendaki kegiatan pembelajaran yang berpusat pada peserta didik, mengembangkan kreativitas peserta didik, menciptakan kondisi menyenangkan dan menantang, bermuatan nilai, etika, estetika, logika, dan kinestetika, serta menyediakan pengalaman belajar yang beragam melalui penerapan pembelajaran yang menyenangkan, kontekstual, efektif, efisien, dan bermakna. Oleh karenanya, pembelajaran matematika di sekolah seharusnya berusaha untuk mengaitkan konten pelajaran dengan konteks kehidupan nyata dengan cara siswa aktif mengkonstruksi suatu pengetahuan berdasarkan pengalaman yang dialaminya. Dengan demikian, pembelajaran matematika akan bermakna, matematika bukanlah sebagai produk, melainkan sebagai suatu proses dan pembelajaran yang berlangsung merangsang siswa untuk mengembangkan kreativitasnya.

Konteks kehidupan nyata yang dialami oleh siswa terkadang penuh dengan tantangan. Tak jarang siswa menemui jalan buntu, merasa frustasi, dan kehabisan akal. Mereka memerlukan arahan dan bimbingan dari guru agar mampu melakukan kreasi terhadap suatu ide matematis. Jika siswa mampu memiliki pemikiran yang kreatif, maka ia akan mampu mengemukakan ide-ide baru dan melakukan inovasi-inovasi baru dalam kehidupan. Menurut Yurniwati (2015: 505-506) bila anak belajar matematika terpisah dari pengalaman mereka sehari-hari maka anak akan cepat lupa dan tidak dapat mengaplikasikan matematika. Sejauh ini, pembelajaran masih didominasi oleh pandangan bahwa pengetahuan sebagai fakta untuk dihafal. Pembelajaran tidak hanya difokuskan pada pemberian pembekalan kemampuan pengetahuan yang bersifat teoritis saja, akan tetapi bagaimana agar pengalaman belajar yang dimiliki siswa itu senantiasa terkait dengan permasalaha-permasalahan aktual yang terjadi di lingkungannya.

Contextual Teaching and Learning atau pembelajaran kontekstual menurut Lestari dan Yudhanegara (2015 : 38,39) adalah suatu pembelajaran yang mengupayakan agar siswa dapat menggali kemampuan yang dimilikinya dengan mempelajari konsep-konsep sekaligus menerapkannya dengan dunia nyata di sekitar 
lingkungan siswa. Contextual Teaching and Learning menurut Howey (Hasibuan, 2014: 3) adalah pembelajaran yang memungkinkan terjadinya proses belajar di mana siswa menggunakan pemahaman dan kemampuan akademiknya dalam berbagai konteks dalam dan luar sekolah untuk memecahkan masalah yang bersifat simulatif ataupun nyata, baik sendirisendiri maupun bersama-sama. Menurut Hasnawati (2012: 50-51) Contextual Teaching and Learning dapat dimulai dengan sajian atau tanya jawab lisan terkait dengan dunia nyata kehidupan siswa, sehingga siswa dapat merasakan manfaat dari materi yang disajikan, motivasi belajar muncul, dunia pikiran siswa menjadi konkret, dan suasana menjadi kondusif, nyaman dan menyenangkan. Dengan ini siswa akan menyadari bahwa apa yang mereka pelajari berguna dalam hidupnya nanti. Sehingga, akan membuat mereka memposisikan sebagai diri sendiri yang memerlukan suatu bekal yang bermanfaat untuk hidupnya dan siswa akan berusaha untuk menggapinya. Rusman (2016 : 187) mengemukakan bahwa Contextual Teaching and Learning adalah usaha untuk membuat siswa aktif dalam memompa kemampuan diri tanpa merugi dari segi manfaat, sebab siswa berusaha mempelajari konsep sekaligus menerapkan dan mengaitkannya dengan dunia nyata. Pembelajaran matematika yang menggunakan Contextual Teaching and Learning siswa diharapkan mampu belajar aktif, belajar melalui pengalaman bukan hanya menerima konsep yang diberikan guru, dan dapat mengkonstruksi pengetahuannya sendiri. Karakteristik pembelajaran Contextual Teaching and Learning adalah pembelajaran dilaksanakan dalam konteks autentik dengan menggali pengetahuan siswa, memberikan tugas-tugas yang bermakna, membentuk kelompok untuk menciptakan kerjasama antar siswa, dan menciptakan pembelajaran yang menyenangkan dengan memberikan pengalaman yang bermakna. Peran guru dalam menerapkan Contextual Teaching and Learning ini adalah untuk membantu siswa mencapai tujuan. Hal ini berarti guru lebih banyak difokuskan kepada strategi daripada memberi informasi. Salah satu usaha guru adalah mengelola kelas sebagai sebuah tim yang bekerja bersama untuk menemukan pengetahuan bagi siswa (Rusyda dan Sari, 2017: 154).

Beberapa prinsip dasar Contextual Teaching and Learning yang perlu diperhatikan menurut Mardapi (Hasnawati, 2006: 57) yaitu menekankan pada pemecahan masalah (problem solving), mengenal kegiatan mengajar terjadi pada berbagai konteks seperti rumah, masyarakat, dan tempat kerja (multiple contex), membantu siswa belajar bagaimana memonitor belajarnya sehingga menjadi individu mandiri (self-regulated learned), menekankan pengajaran dalam konteks kehidupan siswa (life skill education), mendorong siswa belajar dari satu dengan yang lainnya dan belajar bersamasama (cooperative learning), dan menggunakan penilaian autentik (authentic assessment). Hasibuan (2014: 10) mengemukakan langkah-langkah Contextual Teachimg and Learning yaitu mengembangkan pemikiran bahwa anak akan belajar lebih bermakna dengan cara bekerja sendiri, menemukan sendiri, dan mengkonstruksi sendiri pengetahuan dan ketrampilan barunya, melaksanakan sejauh mungkin kegiatan inquiri untuk semua topik, mengembangkan sifat ingin tahu siswa dengan bertanya, menciptakan masyarakat belajar, memberikan contoh yang benar, melakukan refleksi diakhir pertemuan, dan melakukan penilaian yang sebenarnya dengan berbagai cara.

Berpikir kreatif menurut Johnson (2012 : 183) adalah kegiatan mental yang memupuk ideide asli dan pemahaman-pemahaman baru. Menurut La Moma (2015: 29) berpikir kreatif adalah aktivitas mental yang terkait dengan kepekaan terhadap suatu masalah, mempertimbangkan informasi baru dan ide-ide yang tidak biasanya dengan suatu pikiran terbuka, serta dapat membuat hubunganhubungan dalam menyelesaikan suatu masalah. Menurut Slameto (Putra, Irwan, dan Dodi Vionanda, 2012: 23) kemampuan berpikir kreatif adalah suatu proses berpikir yang menghasilkan bermacam-macam kemungkinan ide dan cara secara luas dan beragam. Dalam menyelesaikan suatu persoalan, apabila menerapkan berpikir kreatif, akan menghasilkan banyak ide yang berguna dalam menemukan penyelesaiannya. Kreatif berhubungan dengan penemuan sesuatu, mengenai hal yang menghasilkan sesuatu yang baru dengan mengunakan sesuatu yang telah ada. Purwaningrum (2016: 146) memandang kemampuan berpikir kreatif matematis merupakan produk dari kreativitas matematika sedangkan aktivitas kreatif merupakan kegiatan dalam pembelajaran yang diarahkan untuk 
mendorong atau memunculkan kreativitas siswa. Noer (2009: 523) menyimpulkan ada lima macam perilaku kreatif seseorang secara umum, yaitu kelancaran (fluency) adalah kemampuan untuk mencetuskan banyak gagasan, jawaban, penyelesaian masalah, memberikan banyak cara atau saran dalam melakukan berbagai hal, dan selalu memikirkan lebih dari satu jawaban. Keluwesan (flexibility) adalah kemampuan untuk menghasilkan gagasan, jawaban, atau pertanyaan yang bervariasi, dapat melihat masalah dari sudut pandang yang berbeda, dan mampu mengubah cara pendekatan. Keterperincian (elaboration) adalah kemampuan untuk mengembangkan suatu gagasan, menambah atau memerinci secara detil suatu obyek, gagasan, atau situasi sehingga lebih menarik. Kepekaan (sensitivity) adalah kemampuan untuk menangkap dan menghasilkan masalah-masalah sebagai tanggapan terhadap suatu situasi. Keaslian (originality) adalah kemampuan untuk mengemukakan pendapat dirinya sendiri sebagai tanggapan terhadap suatu situasi yang dihadapi, memikirkan cara yang tidak lazim untuk mengungkapkan diri, dan mampu membuat kombinasi yang tidak lazim.

Kemampuan berpikir kreatif matematis dapat berkembang bila tersedia lingkungan pembelajaran yang memberi ruang bagi pengembangan kemampuan kreatif tersebut. Pengajuan ide yang kreatif dan inovatif dalam pembelajaran matematika dapat meningkatkan kemampuan berpikir kreatif siswa. Dengan meningkatnya kemampuan berpikir kreatif matematis akan memberikan ruang yang luas bagi perkembangan potensi siswa seperti mengembangkan minat, mengasah bakat dan kemampuan, serta memberi kepuasan kepada individu untuk mencapai keberhasilan. Kemampuan berpikir kreatif matematis amat diperlukan baik untuk masa kini maupun masa datang terutama dalam menghadapi situasi dunia yang selalu berubah (Noer, 2009 : 524). Purnomo (2011: 41) menjelaskan kreativitas merupakan kemampuan individu yang dapat berupa cipta, karsa, dan karya seseorang untuk dapat menciptakan sesuatu yang baru ataupun mengembangkan pemikiran alternative. Hal ini dimaksudkan agar individu mampu melihat sesuatu dari berbagai sudut pandang sebagai hasil dari interaksi individu dengan lingkungannya sehingga diperoleh cara-cara baru untuk mencapai tujuan yang lebih bermakna.

Berdasarkan hal-hal yang telah dijelaskan dengan menerapkan pendekatan pembelajaran kontekstual diharapkan adanya perubahan suasana di dalam pembelajaran, membuat siswa lebih semangat di dalam belajar, dan membuat guru lebih kreatif di dalam melaksanakan perencanaan pembelajaran yang telah disusun sebelumnya. Pendekatan kontekstual juga diharapkan dapat menciptakan proses pembelajaran lebih bermakna, menarik, mudah dipahami, dan dapat meningkatkan kemampuan berpikir kreatif siswa. Pendekatan ini lebih melibatkan siswa secara langsung, dan membuat siswa mengalami langsung. Dengan Contextual Teaching and Learning, akan terjalin suasana belajar yang mengutamakan kerja sama, saling menunjang, menyenangkan, tidak membosankan, belajar dengan bergairah, pembelajaran terintegrasi, menggunakan berbagai sumber, siswa aktif, sharing dengan teman, siswa kreatif. Pembelajaran berlangsung secara alamiah dalam bentuk kegiatan siswa bekerja dan mengalami, bukan transfer pengetahuan dari guru. Siswa dapat mengkonstruksikan sendiri pengetahuannya, menemukan sendiri konsep-konsep materi yang sedang dihadapi.

\section{Metode}

Penelitian ini termasuk dalam jenis penelitian eksperimen yang mengukur kemampuan berpikir kreatif matematis siswa dengan menerapkan pendekatan Contextual Teaching and Learning pada kelas eksperimen pokok bahasan pola bilangan kelas VIII SMP Negeri 2 Konawe Selatan. Penelitian ini menggunakan Posttest Only Design dimana siswa pada kelas eksperimen dan siswa pada kelas kontrol diberikan materi pelajaran yang sama, tetapi dengan model pembelajaran yang berbeda. Setelah selesai pembelajaran kedua kelas tersebut diberikan posttest. Hasil rata-rata posttest tersebut dianalisis dengan tes statistik. Penelitian ini dilakukan pada SMP Negeri 2 Konawe Selatan yang beralamat di jalan Alam Ria no. 1, kelurahan Punggaluku, kecamatan Laeya, kabupaten Konawe Selatan pada bulan Juli 2018. Populasi dalam penelitian ini adalah siswa kelas VIII SMP Negeri 2 Konawe Selatan tahun ajaran 2018/2019 semester I yang berjumlah 145 siswa dan terdistribusi dalam 5 
kelas yaitu VIIIA 30 siswa, VIIIB 30 siswa, VIIIC 29 siswa, VIIID 27 siswa, dan VIIIE 29 siswa. Pengambilan sampel dalam penelitian ini dilakukan dengan menggunakan teknik simple random sampling. Sampel yang dibutuhkan dalam penelitian adalah sebanyak dua kelas. Sebelum sampel dipilih terlebih dahulu dilakukan uji homogenitas pada populasi. Data yang diujikan yaitu data hasil tes berpikir kreatif pada saat observasi awal. Uji homogenitas dengan menggunakan SPSS16 menghasilkan nilai sigifikansi variabel kemampuan berpikir kreatif berdasarkan variabel kelas A, B, C, D, dan $\mathrm{E}$ adalah sebesar 0,81>0,05 yang artinya data tersebut mempunyai varian yang sama atau homogen. Selanjutnya dilakukan pengambilan sampel dengan cara undian. Berdasarkan teknik pengambilan sampel tersebut, diperoleh kelas VIIIC dan kelas VIIID dengan jumlah siswa kelas VIIIC sebanyak 29 siswa (13 laki-laki dan 16 perempuan) dan kelas VIIID sebanyak 27 siswa (18 laki-laki dan 9 perempuan) sampel penelitian. Data hasil tes berpikir kreatif pada saat observasi awal disajikan dalam tabel berikut.

\section{Tabel 1}

Hasil Tes Pendahuluan Berpikir Kreatif Siswa Kelas VIII SMP Negeri 2 Konsel

\begin{tabular}{|c|c|c|c|c|c|c|}
\hline \multirow{2}{*}{ Kelas } & \multicolumn{5}{|c|}{ Nilai Rata-rata } & \multirow{2}{*}{ Var. } \\
\cline { 2 - 7 } & Fluency & flexibility & Elaboration & Originality & $\overline{\boldsymbol{x}}$ & \\
\hline A (30 siswa) & 33 & 19 & 22 & 17 & 23 & 79 \\
\hline B (30 siswa) & 31 & 13 & 28 & 16 & 22 & 60 \\
\hline C (29 siswa) & 30 & 16 & 14 & 28 & 22 & 100 \\
\hline D (27 siswa) & 34 & 14 & 28 & 13 & 22 & 89 \\
\hline E (29 siswa) & 28 & 23 & 16 & 19 & 21 & 73 \\
\hline$\overline{\boldsymbol{x}}$ & 31 & 17 & 22 & 18 & 22 & - \\
\hline
\end{tabular}

Instrumen pada penelitian ini terbagi menjadi dua yaitu (a) Lembar observasi aktivitas guru dan siswa, (b) Lembar tes kemampuan berpikir kreatif matematika siswa berupa uraian yang mengacu pada indikator kemampuan berpikir kreatif yang hendak diukur yaitu berpikir lancar (fluency), berpikir luwes (flexibility), berpikir merinci (elaboration), dan berpikir asli (originality). Lembar observasi digunakan untuk mengukur terlaksana atau tidaknya pembelajaran matematika dengan menggunakan pendekatan Contextual Teaching and Learning. Instrumen yang digunakan yaitu berupa format daftar isian yang disusun berdasarkan rencana pelaksanaan pembelajaran (RPP) dan berisi aktivitas-aktivitas dan kejadian atau tingkah laku yang terjadi selama proses pembelajaran. Lembar observasi ini kemudian akan diisi oleh observer yang akan mengamati secara langsung kegiatan pembelajaran yang dilakukan oleh penelti dan siswa. Tes kemampuan berpikir kreatif matematis siswa dilakukan setelah diberi perlakuan (posttest).

Tabel 2

Kompetensi Dasar dan Indikator Pencapaian Kompetensi Materi

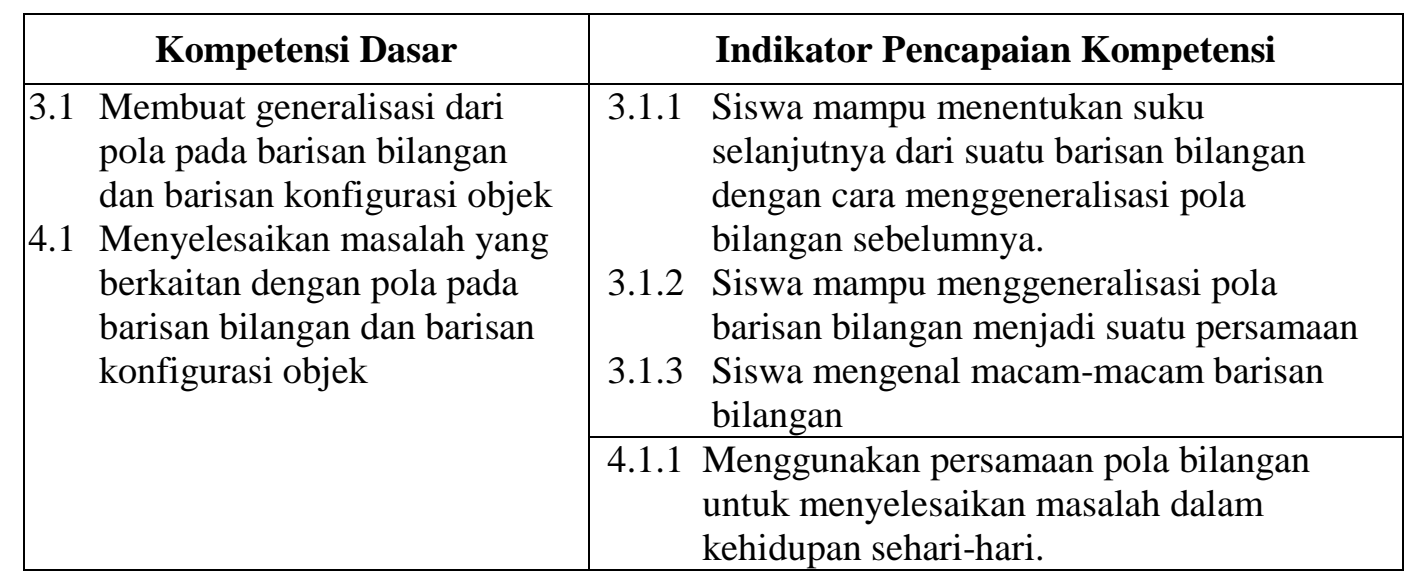


Adapun pedoman pensekoran yang digunakan dalam penelitian ini adalah hasil modifikasi dari Bosch (dalam Fajriyah, 2015: 161) dengan penjelasan sebagai berikut.

1. Kelancaran (Fluency)

$0=$ Tidak menjawab atau memberikan jawaban yang tidak relevan

$1=$ Terdapat kekeliruan dalam mengidentifikasi ide matematis dari kondisi yang diberikan

$2=$ Mampu mengidentifikasi ide matematis dari kondisi yang diberikan dan mengaplikasikannya pada konsep matematika yang kurang tepat

3 = Mampu mengidentifikasi ide matematis dari kondisi yang diberikan, mengaplikasikannya dalam konsep matematis yang tepat namun terdapat kekeliruan dalam penyelesaiannya

$4=$ Mampu mengidentifikasi ide matematis dari kondisi yang diberikan, mengaplikasikannya dalam konsep matematis yang tepat serta benar dalam penyelesaiannya

2. Keluwesan (Flexibility)

$0=$ Tidak menjawab atau memberikan cara/saran yang tidak relevan untuk pemecahan masalah

1 = Memberikan satu cara/saran yang relevan dengan pemecahan masalah tetapi mengungkapkannya kurang jelas

2 = Memberikan satu cara/saran yang relevan dengan pemecahan masalah dan pengungkapkannya lengkap dan jelas

3 = Memberikan lebih dari satu cara yang relevan dengan pemecahan masalah dan pengungkapannya kurang jelas

$4=$ Memberikan lebih dari satu cara/saran yang relevan dan pemecahan masalah dan pengungkapannya lengkap serta jelas

3. Keterincian ( Elaboration)

$0=$ Tidak menjawab atau memberikan jawaban yang salah
1 = Terdapat kekeliruan dalam memahami situasi tanpa disertai perincian

$2=$ Terdapat kekeliruan dalam memperluas situasi dan disertai perincian yang kurang detil

3 = Memperluas situasi dengan benar dan merincinya kurang detil

4 = Memperluas situasi dengan benar dan merincinya dengan detil

4. Keaslian (Originality)

$0=$ Tidak menjawab atau memberi jawaban yang salah

1 = Memberi jawaban dengan caranya sendiri tetapi tidak dapat dipahami

2 = Memberi jawaban dengan caranya sendiri, proses perhitungan sudah terarah tetapi tidak selesai

3 = Memberi jawaban dengan caranya sendiri tetapi terdapat kekeliruan dalam proses perhitungan sehingga hasilnya salah

4 = Memberi jawaban dengan caranya sendiri, proses perhitungan dan hasil benar

\section{Hasil}

Hasil dalam penelitian ini terdiri dari analisis validitas dan reliabilitas instrument penelitian, analisis deskriptif, dan analisis inferensial. Instrumen posttest yang diajukan untuk divalidasi berisi empat butir soal dalam bentuk tes uraian. Instrumen ini telah divalidasi oleh empat orang panelis, terdiri dari dua orang dosen jurusan pendidikan matematika FKIP UHO dan dua guru mata pelajaran matematika dari SMP Negeri 2 Konawe Selatan. Hasilnya, keempat soal tersebut layak untuk digunakan (valid). Setelah itu, instrumen yang terdiri dari empat butir soal tersebut diuji derajat reliabilitasnya. Dengan menggunakan cara manual serta berbantukan program SPSS 16.0 secara ringkas hasilnya dapat dilihat pada tabel berikut.

Tabel 3

Hasil Uji Validitas dan Reliabilitas Instrumen posttest

\begin{tabular}{|c|c|c|c|c|}
\hline \multicolumn{4}{|c|}{ Koefisien Korelasi Butir Soal } & \multirow{2}{*}{ Nilai Alpha } \\
\hline Nomor 1 & Nomor 2 & Nomor 3 & Nomor 4 & \\
\hline 0,9375 & 0,9375 & 1 & 1 & 1,3066 \\
\hline Valid & Valid & Valid & Valid & Reliable \\
\hline
\end{tabular}


Berdasarkan tabel tersebut, nilai koefisien korelasi tiap butir soal $>0,6$ dan nilai alpha $\left(r_{11}\right)$ $>0,6$. Hal ini berarti instrumen posttest tersebut mampu mengukur apa yang hendak diukur (kemampuan berpikir kreatif matematis) dan dapat memberikan hasil yang konsisten (reliable). Analisis deskriptif dimaksudkan untuk mendeskripsikan kemampuan berpikir kreatif matematis siswa kelas VIII SMP Negeri 2 Konawe Selatan setelah diajar menggunakan pendekatan Contextual Teaching and Learning dan pendekatan konvensional. Skor perolehan siswa kemudian dikonversi dalam skala 100. Analisis deskriptif kemampuan berpikir kreatif matematis siswa menggunakan bantuan program SPSS 16.0. Setelah dilakukan pengolahan data nilai posttest pada kelas kontrol dan kelas eksperimen, hasil statistik deskriptif data disajikan sebagai berikut.

Tabel 4

Data Hasil Posttest

\begin{tabular}{|c|c|c|}
\hline Data & $\begin{array}{c}\text { Posstest } \\
\text { Kelas Kontrol }\end{array}$ & $\begin{array}{c}\text { Posttest } \\
\text { Kelas Eksperimen }\end{array}$ \\
\hline Jumlah Sampel & 27 & 23 \\
\hline Mean & 39,59 & 55,60 \\
\hline Median & 31,00 & 62,00 \\
\hline Mode & 25,00 & 75,00 \\
\hline Std. Deviation & 2,20 & 23,25 \\
\hline Variance & 484,63 & 540,70 \\
\hline Kurtosis & $-1,22$ & $-1,64$ \\
\hline Range & 69,00 & 62,00 \\
\hline Minimum & 6,00 & 25,00 \\
\hline Maximum & 75,00 & 87,00 \\
\hline
\end{tabular}

Dari tabel di atas, dapat dilihat bahwa dengan jumlah sampel 50 orang, nilai rata-rata kemampuan berpikir kreatif siswa pada kelas eksperimen lebih tinggi dari kelas kontrol yang dilaksanakan setelah siswa diberikan perlakuan berupa pembelajaran dengan pendekatan Contextual Teaching and Learning. Hal ini dapat diamati dari nilai rata-rata siswa pada kelas kontrol sebesar 39,59 dengan varians
484,63 dan rata-rata siswa pada kelas eksperimen 55,60 dengan varians sebesar 540,70. Deskripsi kemampuan berpikir kreatif matematis siswa kelas VIII SMP Negeri 2 Konawe Selatan ditinjau dari tingkat kreatifitas siswa yang diajar menggunakan pendekatan Konvensional (kelas kontrol) dan pendekatan Contextual Teaching and Learning (kelas eksperimen) ditampilkan pada tabel berikut.

Tabel 5

Distribusi frekuensi berdasarkan interval kelas nilai kemampuan berpikir kreatif matematis siswa kelas VIII SMP Negeri 2 Konawe Selatan

\begin{tabular}{|c|c|c|c|c|}
\hline \multirow[b]{2}{*}{ No. } & \multirow[b]{2}{*}{ Nilai } & \multicolumn{2}{|c|}{ Frekuensi $(f)$} & \multirow[b]{2}{*}{ Tingkat Kreatifitas Siswa } \\
\hline & & $\begin{array}{c}\text { Kelas } \\
\text { Kontrol }\end{array}$ & $\begin{array}{c}\text { Kelas } \\
\text { Eksperimen }\end{array}$ & \\
\hline 1. & $81-100$ & 0 & 3 & Sangat Kreatif \\
\hline 2. & $61-80$ & 7 & 9 & Kreatif \\
\hline 3. & $41-60$ & 6 & 3 & Cukup Kreatif \\
\hline 4. & $21-40$ & 9 & 8 & Kurang Kreatif \\
\hline 5. & $00-20$ & 5 & 0 & Tidak Kreatif \\
\hline
\end{tabular}

Selanjutnya data kelas kontrol dan kelas eksperimen tersebut dihitung berdasarkan indikator masing-masing soal tes berpikir kreatif yang diberikan. Penyajian data berdasarkan indikator berpikir kreatif matermatis kelas VIII 
SMP Negeri 2 Konawe Selatan ditampilkan pada tabel berikut.

Tabel 6

Rata-Rata Nilai Perindikator Berpikir Kreatif Matematis Siswa

\begin{tabular}{|c|c|c|c|}
\hline \multirow{2}{*}{ No. } & \multirow{2}{*}{ Indikator Berpikir kreatif } & \multicolumn{2}{|c|}{ Nilai Rata-Rata } \\
\cline { 3 - 4 } & & Kelas Kontrol & \multirow{2}{*}{ Kelas Eksperimen } \\
\hline 1 & Berpikir Lancar (Fluency) & 79 & 87 \\
\hline 2 & Berpikir Luwes (Flexibility) & 31 & 60 \\
\hline 3 & Berpikir Merinci (Elaboration) & 18 & 23 \\
\hline 4 & Berpikir Asli (Originality) & 30 & 53 \\
\hline
\end{tabular}

Dari tabel rata-rata nilai perindikator berpikir kreatif matematis siswa di atas, dapat diamati bahwa nilai rata-rata pada setiap indikator berpikir kreatif yang diajar menggunakan pendekatan Contextual Teaching and Learning lebih tinggi dibandingkan dengan nilai rata-rata pada setiap indikator berpikir kreatif yang diajar menggunakan pendekatan konvensional. Sementara itu, nilai rata-rata indikator berpikir kreatif tertinggi yang diajar menggunakan pendekatan konvensional (kelas kontrol) adalah pada indikator berpikir lancar yakni 79 dengan kategori kreatif. Demikian juga nilai rata-rata berpikir kreatif tertinggi yang diajar menggunakan pendekatan Contextual Teaching and Learning adalah pada indikator

Tabel 7

berpikir lancar yakni sebesar 87 dengan kriteria sangat kreatif. Hal ini menunjukkan bawa penerapan pendekatan Contextual Teaching and Learning memberikan pengaruh positif terhadap perkembangan kemampuan berpikir kreatif matematis siswa.

Data diperoleh berdasarkan daftar aktivitas guru yang tertera pada lembar observasi yang dibuat berdasarkan tujuh tahapan pendekatan Contextual Teaching and Learning, yaitu kontruktivisme, menemukan, bertanya, masyarakat belajar, memberikan contoh yang benar, melakukan refleksi, dan penilaian yang sebenarnya yang terdiri dari lima pertemuan, disajikan dalam tabel berikut.

Hasil Observasi Aktivitas Guru Kelas Eksperimen

\begin{tabular}{|c|c|c|}
\hline Pertemuan & Persentase $\mathbf{( \% )}$ & Kriteria \\
\hline $\mathbf{1}$ & 69 & Baik \\
\hline $\mathbf{2}$ & 81 & Sangat Baik \\
\hline $\mathbf{3}$ & 81 & Sangat Baik \\
\hline $\mathbf{4}$ & 87 & Sangat Baik \\
\hline $\mathbf{5}$ & 87 & Sangat Baik \\
\hline
\end{tabular}

Berdasarkan tabel tersebut, persentase keberhasilan pengelolaan pembelajaran pada pertemuan pertama mencapai 69\%. Pada pertemuan ini, peneliti masih melakukan penyesuaian terhadap tahap-tahap pendekatan pembelajaran Contextual Teaching and Learning sehingga langkah-langkah pembelajaran yang direncanakan tidak dapat dilaksanakan, seperti memberikan apersepsi kepada siswa dan guru tidak sempat mengatur agar setiap kelompok menjawab pertanyaan kelompok lain akibat alokasi waktu pembelajaran telah habis 
Tabel 8

Hasil Observasi Aktivitas Guru Kelas Kontrol

\begin{tabular}{|c|c|c|}
\hline Pertemuan & Persentase $(\boldsymbol{\%})$ & Kriteria \\
\hline $\mathbf{1}$ & 69 & Baik \\
\hline $\mathbf{2}$ & 85 & Sangat Baik \\
\hline $\mathbf{3}$ & 85 & Sangat Baik \\
\hline $\mathbf{4}$ & 85 & Sangat Baik \\
\hline $\mathbf{5}$ & 85 & Sangat Baik \\
\hline
\end{tabular}

Berdasarkan tabel tersebut, persentase keberhasilan pengelolaan pembelajaran pada pertemuan pertama mencapai 69\%. Pada pertemuan ini, peneliti masih melakukan penyesuaian terhadap tahap-tahap pendekatan pembelajaran konvensional sehingga langkahlangkah pembelajaran yang direncanakan tidak dapat dilaksanakan, seperti memotivasi siswa untuk aktif dalam pembelajaran dan peneliti tidak menyampaikan tujuan pembelajaran. Data diperoleh berdasarkan observasi terhadap keaktifan siswa dalam pelaksanaan pembelajaran matematika dengan menggunakan pendekatan Contextual Teaching and Learning oleh peneliti yang tertera pada lembar observasi yang ada pada setiap pembelajaran. Tingkat keaktifan siswa selama lima kali pelaksanaan pembelajaran terus meningkat.

Tabel 9

Hasil Observasi Aktivitas Siswa Kelas Eksperimen

\begin{tabular}{|c|c|c|}
\hline Pertemuan & Persentase (\%) & Kriteria \\
\hline $\mathbf{1}$ & 50 & Sedang \\
\hline $\mathbf{2}$ & 79 & Baik \\
\hline $\mathbf{3}$ & 79 & Baik \\
\hline $\mathbf{4}$ & 86 & Sangat Baik \\
\hline $\mathbf{5}$ & 93 & Sangat Baik \\
\hline
\end{tabular}

Tingkat keaktifan siswa selama lima kali pelaksanaan pembelajaran terus meningkat. Data yang diperoleh menunjukkan bahwa dari 14 deskriptor keaktifan siswa pada pertemuan pertama di tahap pendahuluan siswa tidak menerima apersepsi dari guru dan dalam menjelaskan strategi pembelajaran siswa tidak melakukan tanya jawab dengan guru seputar tugas yang diberikan, pada tahap kegiatan inti dalam penerapan pendekatan pembelajaran siswa tidak melakukan pencatatan pada hal-hal yang ditemukan selama observasi bahkan siswa tidak mendiskusikan hasil temuannya dengan kelompok sedangkan dalam penilaian hasil belajar masing-masing anggota kelompok tidak menjawab pertanyaan kelompok lain. Hal ini dikarenakan peneliti sebagai pengajar tidak memberi arahan kepada siswa. Akan tetapi, persentasi keaktifan siswa meningkat pada pertemuan kedua sampai kelima sekalipun persentasi keaktifan siswa pada pertemuan kedua sampai ketiga tetap atau tidak mengalami perubahan. Peneliti menilai hal ini mungkin terjadi karena siswa telah terbiasa dengan sistem pembelajaran yang direncanakan meskipun peneliti tidak secara langsung menyampaikan langkah-langkah pembelajaran Contextual Teaching and Learning kepada siswa.

Data keaktifan siswa pada kelas kontrol yang diajar dengan pendekatan konvesnsional berdasarkan lembar observasi tertera pada tabel berikut. 
Tabel 10

Hasil Observasi Aktivitas Siswa Kelas Kontrol

\begin{tabular}{|c|c|c|}
\hline Pertemuan & Persentase (\%) & Kriteria \\
\hline $\mathbf{1}$ & 70 & Baik \\
\hline $\mathbf{2}$ & 90 & Sangat Baik \\
\hline $\mathbf{3}$ & 90 & Sangat Baik \\
\hline $\mathbf{4}$ & 80 & Baik \\
\hline $\mathbf{5}$ & 80 & Baik \\
\hline
\end{tabular}

Tingkat keaktifan siswa selama lima kali pelaksanaan pembelajaran meningkat pada pertemuan kedua adn ketiga. Data yang diperoleh menunjukkan bahwa dari 10 deskriptor keaktifan siswa pada pertemuan pertama di tahap pendahuluan siswa tidak dijelaskan tujuan pembelajaran yang harus dicapai, pada tahap kegiatan inti tidak berani menuliskan jawaban dari soal latihan yang telah dikerjakan. Persentasi keaktifan siswa meningkat pada pertemuan kedua dan ketiga, akan tetapi menurun pada pertemuan keempat dan kelima.

Analisis inferensial dimaksudkan untuk menguji pengaruh pendekatan Contextual Teaching and Learning terhadap kemampuan berpikir kreatif matematis siswa. Analisis inferensial terdiri dari analisis prasyarat dan uji hipotesis. Analisis prasyarat yang digunakan dalam penelitian ini adalah uji normalitas dimaksudkan untuk menguji kenormalan data dan uji homogenitas dimaksudkan untuk mengetahui apakah varians data kedua kelompok yang diteliti mempunyai varians yang homogen atau tidak. Jika data berdistribusi normal, maka pengujian hipotesis menggunakan hipotesis parametrik.

Hipotesis:

$\mathrm{H}_{0}$ : data berdistribusi normal

$\mathrm{H}_{1}$ : data tidak berdistribusi normal

Kriteria pengambilan keputusan: terima $\mathrm{H}_{0}$ jika nilai Sig $(2-$ tailed $) \geq \alpha=0,05$

Hasil uji $\mathrm{K}-\mathrm{S}$ tersebut dengan bantuan SPSS 16.0 disajikan dalam table berikut.

\section{Tabel 11}

Hasil uji K- S (uji normalitas) data posttest

\begin{tabular}{|c|c|c|c|}
\hline Data & Sig. & $\alpha$ & Keputusan \\
\hline 50 & 0,07 & 0,05 & Terima $\mathrm{H}_{0}$ \\
\hline
\end{tabular}

Berdasarkan tabel tersebut, karena nilai Sig. > 0,05 sehingga diputuskan terima $\mathrm{H}_{0}$. Kesimpulannya adalah data pada kelas kontrol dan kelas eksperimen berdistribusi normal. Karena berdistribusi normal maka pengujian dilanjutkan dengan uji homogenitas. Uji homogenitas dilakukan dengan bantuan
Hipotesis:

$\mathrm{H}_{0}$ : kedua varians homogen

$\mathrm{H}_{1}$ : kedua varians tidak homogeny

Kriteria pengambilan keputusan: terima $H_{0}$ jika nilai Sig $\geq \alpha=0,05$

Hasil uji dapat disajikan dalam tabel berikut. SPSS16.0.

Tabel 12

Hasil Uji homogenitas data posttest

\begin{tabular}{|c|c|c|c|}
\hline Data & Sig. & $\alpha$ & Keputusan \\
\hline 50 & 0,42 & 0,05 & Terima $\mathrm{H}_{0}$ \\
\hline
\end{tabular}

Berdasarkan tabel tersebut, karena nilai Sig. > 0,05 sehingga diputuskan terima $\mathrm{H}_{0}$.
Kesimpulannya adalah data pada kelas kontrol dan kelas eksperimen homogen atau memiliki 
varians yang sama. Setelah uji prasyarat, diperoleh hasil bahwa nilai pada kelas kontrol dan kelas eksperimen siswa berdistribusi normal dan variansnya sama. Oleh karena itu, data pada kelas kontrol dan kelas eksperimen kemampuan berpikir kreatif matematis siswa diuji menggunakan Paired sample t-test. Uji hipotesis merupakan langkah atau prosedur untuk menentukan apakah hipotesis diterima atau ditolak.

Hipotesis yang diajukan dalam penelitian ini adalah:

$\mathrm{H}_{0}$ : Tidak terdapat pengaruh yang signifikan pendekatan Contextual Teaching and

Tabel 13

Hasil uji $t$ (uji perbedaan rata - rata) data posttest kelas kontrol dan kelas eksperimen

\begin{tabular}{|c|c|c|c|}
\hline $\boldsymbol{t}$ hitung & Sig. (2-tailed) & $\alpha$ & Keputusan \\
\hline 2,499 & 0,016 & 0,05 & tolak $H_{0}$ \\
\hline
\end{tabular}

Berdasarkan tabel tersebut, jika dilihat dari uji t dengan $\mathrm{df}=48$ dan signifikansi $\alpha=5 \%$ diperoleh $t_{\text {tabel }}$ 1,677. Dengan menggunakan nilai $\mathrm{t}$ hitung untuk pengambilan keputusan dimana terima $H_{0}$ jika $t_{h i t} \leq t_{\alpha ;(n 1+n 2-2)}$, karena $t_{\text {hit }}=2,499>1,677=t_{\text {tabel }}$ dan nilai $\frac{\text { Sig. }(2 \text {-tailed })}{2}=0,008<0,05$, sehingga diputuskan tolak $H_{0}$. Kesimpulannya adalah terdapat pengaruh yang signifikan pendekatan Contextual Teaching and Learning terhadap kemampuan berpikir kreatif matematis siswa kelas VIII SMP Negeri 2 Konawe Selatan.

\section{Pembahasan}

Penelitian ini dilakukan dalan 6 kali pertemuan. Pertemuan pertama hingga kelima dilaksanakan pembelajaran dengan materi ajar yang diberikan yaitu pola bilangan dan menggunakan pendekatan Contextual Teaching and Learning pada kelas VIIID sebagai kelas eksperimen dan pendekatan konvensional pada kelas VIIIC sebagai kelas kontrol. Setelah lima kali pertemuan pembelajaran, pada pertemuan keenam dilaksanakan posttest. Guru pengajar pada pelaksanaan pembelajaran di kelas adalah peneliti. Pengamat aktivitas guru pengajar dan pengamat aktivitas siswa dilakukan oleh observer. Alokasi waktu pembelajaran matematika wajib pada tiap pekan adalah 5 jam pelajaran. Untuk tiap pertemuan alokasi waktunya berbeda, yaitu $2 \times 40$ menit dan $3 \times$ 40 menit, sedangkan pada saat pelaksanaan
Learning terhadap kemampuan berpikir kreatif matematis siswa kelas VIII SMP Negeri 2 Konawe Selatan.

$\mathrm{H}_{1}$ : Terdapat pengaruh yang signifikan pendekatan Contextual Teaching and Learning terhadap kemampuan berpikir kreatif matematis siswa kelas VIII SMP Negeri 2 Konawe Selatan.

Kriteria Pengambilan Keputusan:

Terima $\mathrm{H}_{0}$ jika $\mathrm{t}_{\text {hitung }} \leq \mathrm{t}_{\left(\left(\alpha ; \mathrm{n}_{1}+\mathrm{n}_{2}-2\right)\right)}$,

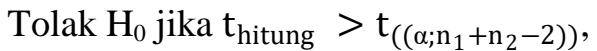

Hasil uji $t$ tersebut disajikan dalam tabel berikut. posttest diberikan alokasi waktu masing masing $3 \times 40$ menit (120 Menit).

Pendekatan Contextual Teaching and Learning terdiri dari tujuh tahap, yaitu tahap konstruktivisme (Contructivism), tahap menemukan (inquiry), tahap bertanya (questioning), tahap masyarakat belajar (learning community), tahap pependekatanan (pendekatanling) dan tahap refleksi (reflection), dan penilaian yang sebenarnya (authentic assessment ), namun dalam pelaksanaannya tidak langsung pada tahap pertama pendekatan Contextual Teaching and learning tetapi dibungkus oleh tiga tahap yaitu tahap pendahuluan, tahap kegiatan inti dan tahap penutup sehingga ketujuh tahap Contextual Teaching and learning tersebut diapit oleh tahap pembuka dan tahap penutup. Selama lima pertemuan pembelajaran, diperoleh data aktivitas guru dan siswa dalam mengelola dan mengikuti jalannya pembelajaran yang dilaksanakan. Berdasarkan lembar observasi, persentase pengelolaan pembelajaran oleh guru tidak pernah mencapai $100 \%$. Peneliti sebagai pengajar mengakui bahwa penerapan pendekatan pembelajaran Contextual Teaching and Learning bukanlah hal mudah terutama bagi guru atau pengajar, karena dalam penerapannya peneliti harus benar-benar mempunyai wawasan yang luas dan peka dengan lingkungan sekitar sehingga apapun dapat dijadikan contoh terkait materi pelajaran. Selain itu peneliti merasa waktu terbatas sehingga pada pelaksanaan pembelajaran, ada langkah-langkah yang 
direncanakan tidak dapat dilaksanakan. Juga, tidak jarang masalah yang dihadapi siswa tidak dapat diselesaikan dengan baik, disebabkan oleh ketidakmampuan siswa dalam menyelesaikan masalah-masalah berkaitan kemampuan berpikir kreatif. Untuk itu, apabila siswa kesulitan menyelesaikan masalah, sehingga mengalami kekeliruan atau bahkan sama sekali tidak tau peneliti hanya menjelaskan proses penyelesaian masalah di papan tulis atau memberikan kesempatan pada siswa yang tau untuk menyelesaikannya di papan tulis.

Pada setiap pertemuan peneliti melalui tiga tahap pembelajaran di masing-masik kelas kontrol dan kelas eksperimen, yaitu tahap pendahuluan, tahap kegiatan inti dan tahap kegiatan penutup. Pada tahap pendahuluan ada dua aspek, yaitu membuka pelajaran dan menjelaskan strategi pembelajaran. Tahap kegiatan inti meliputi penerapan pendekatan pembelajaran dan pemanfaatan sumber belajar dan penilaian hasil belajar. Pada tahap menutup pelajaran peneliti bersama siswa menyimpulkan materi yang diajarkan, memberikan latihan, dan menutup pertemuan dengan mengucapkan salam. Di kelas eksperimen pada pertemuan pertama, setelah peneliti membuka pelajaran peneliti tidak menjelaskan prosedur pembelajaran Contextual Teaching and Learning, karena siswa sudah memiliki kelompok permanen di kelas maka peneliti langsung memberikan sedikit materi kemudian memberikan tugas kepada kepada masingmasing kelompok untuk melakukan observasi tentang materi dan mencatat hasil observasinya. Setelah itu peneliti melakukan tanya jawab dengan siswa seputar tugas yang diberikan, memberikan kesempatan kepada siswa melakukan presentasi hasil diskusi kelompoknya meskipun tidak semua kelompok dalam kelas berkesempatan melakukan presentasi karena waktu terbatas, memberikan kesempatan kepada kelompok lain untuk bertanya, melakukan pemodelan atau memberikan contoh yang benar terkait masalah yang diberikan sehingga pada tahap inilah peneliti membuat model dengan mengambil contoh dalam kehidupan sehari-hari dan dikaitkan dengan materi, melakukan refleksi, memberikan latihan sebagai penilaian terhadap siswa, bersama siswa menyimpulkan materi yang diajarkan, dan menutup pelajaran dengan mengucapkan salam.
Pada pertemuan kedua, peneliti melakukan tahapan yang sama dengan pertemuan pertama akan tetapi pada pertemuan pertama peneliti tidak meminta siswa mencatat hal-hal penting yang ditemukan ketika observasi dan siswa tidak diberikan kesempatan untuk mendiskusikan hasil temuannya dengan kelompok, sementara pada pertemuan kedua peneliti melakukan kedua hal tersebut. Ketika masuk dalam tahap presentasi kelompok, peneliti memberikan kesempatan kepada kelompok yang berbeda dari kelompok yang telah tampil pada pertemuan sebelumnya. Hal ini sama pada pertemuan ketiga sampai keempat, sedangkan pada pertemuan kelima peneliti hampir melakukan semua tahap pembelajaran misalnya meminta siswa untuk melakukan pencatatan pada hal-hal penting yang ditemukan selama observasi, presentasi kelompok juga dapat dilakukan oleh semua kelompok karena peneliti membagi setiap soal pada tugas yang diberikan sehingga setiap kelompok mempresentasikan satu soal saja. Berdasarkan rata-rata hasil observasi aktivitas guru dalam pelaksanaan pendekatan Contextual Teaching and Learning dapat dikatakan bahwa pencapaian keterlaksanaan pembelajaran tergolong hampir berhasil (> 80\%). Adapun hasil observasi keaktifan siswa, pencapaian keterlaksanaan pembelajaran di pertemuan kedua sampai keempat meningkat dari pertemuan pertama meskipun peningkatannya tetap sehingga menunjukkan tanda-tanda siswa memenuhi kriteria kompetensi inti yang diinginkan.

Pendekatan konvensional terdiri dari enam tahapan, yaitu menerangkan bahan ajar, memberikan contoh-contoh, membuka sesi tanya jawab, pemberian tugas, mengkonfirmasi tugas yang dikerjakan siswa, dan menyimpulkan inti pelajaran yang terdiri dari lima pertemuan dimana dalam pelaksanaannya pendekatan ini terdiri dari tahap pendahuluan, tahap kegiatan inti, dan tahap penutup. Pertemuan pertama tahapan pembelajaran yang dilakukan peneliti tidak mencapai $70 \%$ sedangkan pada pertemuan kedua sampai kelima meningkat menjadi $85 \%$. Meningkatnya persentasi keterlaksanaan pembelajaran dikarenakan peneliti melakukan evaluasi dari pertemuan pertama. Hasil observasi keaktifan siswa pada pertemuan pertama mencapai $70 \%$ dan meningkat menjadi 90\% pada pertemuan kedua dan ketiga, akan 
tetapi menurun menjadi $80 \%$ pada pertemuan keempat dan kelima. Menurunnya persentasi keaktifan siswa dalam pembelajaran di kelas karena berbagai faktor, misalnya pendekatan pembelajaran yang membosankan bagi siswa. Guru memberikan contoh-contoh soal yang umumnya ada di buku paket, guru hanya menjelaskan sesuai dengan jawaban pada buku paket, siswa tidak diminta untuk mengkostruksi sendiri materi. Dalam hal ini siswa tidak mengalami langsung apa yang mereka pelajari, siswa hanya mendengarkan apa yang dijelaskan oleh guru, bisa jadi siswa tidak berusaha memahami materi sehingga hal ini membosankan bagi siswa.

Setelah proses pembelajaran selesai, pada pertemuan keenam diadakan posttest. Kemudian, data hasil posttest tersebut diolah menggunakan SPSS untuk menguji apakah dengan pendekatan Contextual Teaching and Learning memberikan pengaruh pada kemampuan berpikir kreatif matematis siswa kelas VIIID SMP Negeri 2 Konawe Selatan. Hasil analisis deskriptif data postest menunjukkan rataan nilai siswa dalam hal ini menggambarkan kemampuan berpikir kreatif matematisnya, setelah diajar menggunakan pendekatan Contextual Teaching and Learning lebih tinggi dibandingkan dengan menggunakan pendekatan konvensional yakni untuk posttest kelas menggunakan pendekatan Contextual Teaching and Learning 55,60 dan untuk posttest kelas menggunakan pendekatan konvensional 39,59. Median setelah diajar menggunakan pendekatan Contextual Teaching and Learning dan setelah diajar menggunakan pendekatan konvensional secara berturut-turut 62,00 dan 31,00. Demikian pula modus setelah diajar menggunakan pendekatan Contextual Teaching and Learning dan setelah diajar menggunakan pendekatan konvensional secara berturut-turut 75,00 dan 25,00.

Setelah dianalisis, pendekatan Contextual Teaching and Learning memberikan pengaruh pada kemampuan berpikir kreatif matematis siswa. Secara akumulatif, terdapat 9 siswa $(39,13 \%)$ yang mempunyai nilai dengan kriteria "kreatif" dan 3 siswa $(13,04 \%)$ dengan kriteria "sangat kreatif" setelah diajar dengan menggunakan pendekatan Contextual Teaching and Learning. Sedangkan pada siswa yang diajar dengan pendekatan konvensional, ada 7 siswa $(30,43 \%)$ yang mempunyai nilai dengan kriteria "kreatif"dan tidak ada $(0,00 \%)$ yang memiliki nilai dengan kriteria "sangat kreatif". Berdasarkan rata-rata pencapaian kemampuan berpikir kreatif siswa perindikator setelah diajar menggunakan pendekatan konvensional secara berturut-turut kemampuan berpikir lancar, berpikir luwes, berpikir merinci, dan berpikir asli adalah 79, 31, 18, dan 30. Adapun setelah diajar menggunakan pendekatan Contextual Teaching and Learning secara berturut-turut berpikir lancar, berpikir luwes, berpikir merinci, dan berpikir asli masing-masing 87, 60, 23, dan 53. Data ini menunjukkan bahwa indikator berpikir kreatif matematis siswa yang diajar menggunakan pendekatan Contextual Teaching and Learning (kelas eksperimen) lebih tinggi dari siswa yang diajar menggunakan pendekatan konvensional (kelas kontrol), dimana indikator berpikir lancar lebih tinggi dan indikator berpikir merinci paling rendah. Untuk indikator berpikir lancar sebanyak 16 dari 23 siswa pada kelas yang diajar menggunakan pendekatan Contextual Teaching and Learning dan sebanyak 19 dari 27 siswa pada kelas yang diajar menggunakan pendekatan konvensional mampu mengidentifikasi ide matematis dari kondisi yang diberikan, mengaplikasikannya dalam konsep matematis yang tepat serta benar dalam penyelesaiannya. Untuk indikator berpikir luwes sebanyak 5 dari 23 siswa pada kelas yang diajar menggunakan pendekatan Contextual Teaching and Learning dan tidak ada siswa pada kelas yang diajar menggunakan pendekatan konvensional yang mampu memberikan lebih dari satu cara yang relevan dengan pemecahan masalah dan pengungkapannya lengkap dan jelas. Untuk indikator berpikir merinci tidak ada siswa pada kelas yang diajar menggunakan pendekatan Contextual Teaching and Learning maupun pada kelas yang diajar menggunakan pendekatan konvensional mampu memperluas situasi dengan benar dan merincinya dengan detil.

\section{Simpulan dan Saran}

\section{Simpulan}

Berdasarkan hasil analisis dan pembahasan, maka peneliti menyimpulkan terkait kemampuan literasi matematis siswa, sebagai berikut:

1. Kemampuan berpikir kreatif matematis siswa kelas VIII SMP Negeri 2 Konawe Selatan setelah diajar dengan pendekatan 


\section{Jurnal Penelitian Pendididikan Matematika Volume 7 No. 1 Januari 2019}

pembelajaran konvensional memiliki nilai rata - rata 39,59. Varians dan std. deviasi masing-masing sebesar 484,635 dan 2,20. Median 31,00 dan modus 25,00. Berdasarkan analisis data, tidak terdapat siswa dengan kategori Sangat kreatif, 7 siswa kreatif, 6 siswa cukup kreatif, 9 siswa kurang kreatif dan 5 siswa dalam kategori tidak kreatif. Nilai rata-rata hasil tes berpikir kreatif matematis siswa kelas VIII SMP Negeri 2 Konawe Selatan setelah diajar dengan pendekatan pembelajaran konvensional untuk indikator berpikir lancar 79, berpikir luwes 31 , berpikir merinci 18 , dan berpikir asli 30 .

2. Kemampuan berpikir kreatif matematis siswa kelas VIII SMP Negeri 2 Konawe Selatan setelah diajar dengan pendekatan Contextual Teaching and Learning memiliki nilai rata rata 55,60. Varians dan std. deviasi masingmasing sebesar 540,70 dan 23,25. Median 62,00 dan modus 75,00. Berdasarkan analisis data, terdapat 3 siswa dengan kategori Sangat kreatif, 9 siswa kreatif, 3 siswa cukup kreatif, 8 siswa kurang kreatif dan tidak terdapat siswa dalam kategori tidak kreatif. Nilai ratarata hasil tes berpikir kreatif matematis siswa kelas VIII SMP Negeri 2 Konawe Selatan setelah diajar dengan pendekatan Contextual Teaching and Learning untuk indikator berpikir lancar 87, berpikir luwes 60, berpikir merinci 23, dan berpikir asli 53.

3. Berdasarkan hasil interpretasi keterlaksanaan pembelajaran dan rata-rata persentasi keaktifan siswa dikategorikan baik, rata-rata nilai kemampuan berpikir kreatif matematis siswa yang diajar dengan pendekatan Contextual Teaching and Learning lebih tinggi, dan uji hipotesis menolak hipotesis nihil sehingga terdapat pengaruh Pendekatan Contextual Teaching and Learning terhadap kemampuan berpikir kreatif matematis siswa kelas VIII SMP Negeri 2 Konawe Selatan.

\section{Saran}

Sehubungan dengan hasil penelitian ini, maka peneliti meyarankan sebagai berikut:

1. Bagi peneliti pendekatan Contextual Teaching and Learning dapat menjadi variasi pembelajaran di sekolah karena dapat berpengaruh terhadap kemampuan berpikir kreatif matematis yang merupakan salah satu kemampuan berpikir tingkat tinggi/HOTS (hing ordered thinking skills) yang termuat dalam kurikulum K13 serta ujian nasional.

2. Dengan adanya beberapa keterbatasan dalam penelitian ini, seperti pada indikator berpikir merinci yang sangat rendah sebaiknya dilakukan penelitian yang lebih lanjut untuk meneliti tentang pembelajaran dengan pendekatan Contextual Teaching and Learning pada pokok bahasan yang cocok atau pada jenjang sekolah yang berbeda.

\section{Daftar Pustaka}

Hasibuan, Idrus. (2014). Model Pembelajaran CTL (Contextual Teaching And Learning). Logaritma. 2(1).

Hasnawati. (2006). Pendekatan Contextual Teaching Learning Hubungannya dengan Evaluasi Pembelajaran. jurnal Ekonomi dan Pendidikan. 3(1).

Jonson, Elaine B. (2010). CTL Contextual Teaching \& Learning Menjadikan Kegiatan Belajar Mengajar Mengasyikkan dan Bermakna. Bandung: Kaifa.

La Moma. (2015). Pengembangan Instrumen Kemampuan Berpikir Kreatif Matematis Untuk Siswa SMP. Jurnal Matematika dan Pendidikan matematika. 4(1): 28 .

Lestari, Karunia Eka dan Mokhammad Ridwan Yudhanegara. (2015). Penelitian Pendidikan Matematika. Bandung: Reflika Aditama.

Noer, Sri Hastuti. (2009). Kemampuan Berpikir Kreatif Matematis: Apa, Mengapa, dan Bagaimana? Prosiding Seminar Nasional Penelitian, Pendidikan dan Penerapan MIPA Fakultas MIPA Universitas Negeri Yogyakarta.

Purwaningrum. (2016). Mengembangkan Kemampuan Berpikir Kreatif Matematis Melalui Discovery Learning Berbasis Scientific Approach. Jurnal Refleksi Edukatia. 6(2).

Purnomo, Yoppy Wahyu. (2011). Keefektifan Model Penemuan Terbimbing dan Cooperative Learning pada Pembelajaran Matematika. Jurnal Kependidikan. 41(1). 